This is the post-print version of the following article:

Gistri, G., Pace, S., Corciolani, M. (2018) "The interaction effect between brand identification and personal crisis relevance on consumers' emotional reactions to a fashion brand crisis", Journal of Global Fashion Marketing, 9, 3, 252-269, DOI 10.1080/20932685.2018.1461021.

The final publication is available at:

https://www.tandfonline.com/doi/abs/10.1080/20932685.2018.1461021 


\title{
The interaction effect between brand identification and personal crisis relevance on consumers' emotional reactions to a fashion brand crisis
}

\author{
Giacomo Gistria*, Matteo Corciolani ${ }^{\mathrm{b}}$, and Stefano Pace ${ }^{\mathrm{c}}$ \\ ${ }^{a}$ Department of Political Science, Communication and International Relations, University of \\ Macerata, Macerata, Italy; ${ }^{b}$ Department of Economics and Management, University of Pisa, \\ Pisa, Italy; ${ }^{c}$ Kedge Business School, Marseille, France
}

*via Don Minzoni, 22a 62100 Macerata (Italy), giacomo.gistri@unimc.it

Giacomo Gistri, PhD, is Associate Professor of Marketing at the Department of Political Sciences, Communication and International Relations, University of Macerata (Italy). He obtained his $\mathrm{PhD}$ at the University of Parma (Italy). He has been a Visiting Research Scholar at Southern Illinois University at Carbondale. His research interests include consumer behavior and marketing communications. He has published in academic journals, including the International Journal of Advertising, Marketing Letters, Journal of Marketing Communication, and Journal of Brand Management.

Matteo Corciolani, $\mathrm{PhD}$, is an Associate Professor at the Department of Economics and Management, University of Pisa (Italy). He has a PhD in Business Administration from the University of Pisa. He teaches Consumer Behavior and Marketing Communications, and his research interests focus mainly on consumer behavior. His projects include the consumption of authentic items, consumption communities, cause-related marketing, and crisis management. He has published in the International Journal of Market Research, Management Decision, and Marketing Theory.

Stefano Pace, $\mathrm{PhD}$, is Associate Professor in Consumer Behavior and Marketing at Kedge Business School (Marseille, France). He obtained his $\mathrm{PhD}$ in Business Administration \& Management at Bocconi University (Milan, Italy), where he has been the Director of the Master in Marketing \& Communication and currently teaches courses in consumer behavior. He has been a visiting $\mathrm{PhD}$ student at the Wharton Business School (Philadelphia, PA) and visiting scholar at the University of Bath (School of Management) and the Karlstad University (CTF, Service Research Center; Sweden). His research interests mainly relate to consumer behavior in the online and offline domains. His publications include articles in international peer-reviewed journals, such as Organization, Journal of Business Ethics, Marketing Theory, Marketing Letters, International Marketing Review, European Journal of Marketing, and Group Decision and Negotiation. 


\title{
The interaction effect between brand identification and personal crisis relevance on consumers' emotional reactions to a fashion brand crisis
}

\begin{abstract}
An organizational crisis is an event perceived by managers and stakeholders as highly salient, unexpected, and potentially disruptive; it can also threaten an organization's goals and have profound implications for its relationships with stakeholders. In this article, we consider an actual crisis that recently struck an important brand in the fashion sector-Moncler. The crisis endured by Moncler was complex, involving several aspects of its activity. Notably, our study was conducted at the beginning of November 2014, in the two weeks after the crisis event. In particular, to collect data on consumers' reactions to Moncler crisis, we created a questionnaire and ran a web survey through Survey Monkey. Then, through a moderated mediation model, we show that the impact of brand identification (BI) on the attitude toward the company (ATC) and purchase intention (PI) is significantly mediated by anger for high levels of personal crisis relevance (PCR) and by sympathy for average and low PCR levels. These results are in accordance with some streams of research concerning the role of emotions, which can perform different functions; the function of emotions such as anger and sympathy is to support the individual's commitment and relate to moral decisions and judgements.
\end{abstract}

Keywords: fashion brands; personal crisis relevance; brand identification; sympathy; anger

\section{Extended Abstract}

An organizational crisis is an event perceived by managers and stakeholders as highly salient, unexpected, and potentially disruptive; it can also threaten an organization's goals and have profound implications for its relationships with stakeholders. Consequently, scholars are increasingly interested in analyzing the emergence of crises and the strategies that can be used to face them. In this article, we consider an actual crisis that recently struck an important brand in the fashion sector-Moncler.

On 2 November 2014, in fact, the Italian television newsmagazine Report released a journalistic inquiry on the illegal practice of live plucking geese in certain regions of Eastern 
Europe. The news program then linked this practice to the manufacturing of the Moncler down jackets. The inquiry also showed the outsourcing of some phases of the manufacturing and the extremely high margins of the fashion industry, with production costs in the order of $€ 30-50$ and retail prices in the range of $€ 1,500-2,000$ for a jacket or dress. Therefore, the inquiry stemmed a public debate and there was uproar against fashion companies, especially the Moncler brand.

Notably, the crisis endured by Moncler was particularly complex, involving several aspects of its activity. The main accusation against Moncler regarded the treatment of geese, and this could be classified as a preventable type of crisis. In addition, the accusation referred to the entire fashion sector in terms of its prices, which were perceived as unjustified, and the practice of outsourcing manufacturing during an economic downturn. According to consumer perception, in fact, companies should support their own national economies during difficult economic times instead of outsourcing production.

In our study, we focused on the emotional impact of crises on stakeholders. Indeed, the ways in which stakeholders perceive and react to crises, as well as the ways in which organizations may influence these perceptions, are generally deemed to have key importance in the literature (Bundy et al., 2016). In particular, we aimed to more deeply analyze the role of emotions in responses to crises by concentrating on a specific category of stakeholders - the final customers. In fact, it has been shown that, in times of crisis, negative customers reaction may pose one of the greatest threats to a company. Moreover, consumer-felt emotions have been considered important elements in explaining how consumers react to company crises (Coombs, 2007). However, despite their central role, they have been understudied to date (Grappi \& Romani, 2015). We thus concentrated on two specific emotions (anger and sympathy) and showed their role in consumer responses to organizational crises. By also referring to the concepts of brand identification (BI) and personal crisis relevance (PCR), more in detail, we expected an asymmetry between anger and sympathy depending on the level of PCR. That is, we hypothesized that a high PCR would prime anger, while a low PCR would prime sympathy. Therefore, the two emotions should differently mediate the effect of $\mathrm{BI}$ on consumers' reactions. 
To collect data on consumers' reactions to Moncler crisis, we created a questionnaire and ran a web survey through Survey Monkey. The study was conducted at the beginning of November 2014, in the two weeks after the crisis event. One hundred and fifteen Moncler consumers (34 men, 81 women; mean age, 28.35 years) responded to the survey. The first part of the questionnaire reminded them of the recent Moncler crisis, detailing the allegations against the company put forward by the television program (Report). The second part of the questionnaire included previously tested scales that were used to measure the constructs of interest. In the last section, some sociodemographic items were included.

Through a moderated mediation model, we then showed that final customer responses to a real fashion brand crisis in terms of attitude toward the company (ATC) and purchase intention (PI) may be predicted. Specifically, we confirmed that the impact of BI on ATC and PI is significantly mediated by anger for high levels of PCR and by sympathy for average and low PCR levels. In other words, we found two different emotional patterns of customer reactions after a fashion brand crisis based on the perception of PCR. When customers perceive the crisis as highly relevant, the emotion that mediates the impact of BI on ATC and PI is anger. In contrast, when the crisis is perceived as having low relevance, the emotion that mediates the impact of BI on ATC and PI is sympathy.

These results corroborate the theoretical expectations illustrated in the paper. A crisis triggers different emotional paths depending on PCR. The results are in accordance with some streams of research concerning the role of emotions, which can perform different functions; the function of emotions like anger and sympathy is to support the individual's commitment and relate to moral decisions and judgements. Thus, emotions help drive the connection between $\mathrm{BI}$ and the effects of the crisis.

\section{Introduction}

An organizational crisis is an event perceived by managers and stakeholders as highly salient, unexpected, and potentially disruptive; it can also threaten an organization's goals and have profound implications for its relationships with stakeholders (Bundy, Pfarrer, Short, \& Coombs, 2016). Recently, even important and legitimated companies, such as Volkswagen (Siano et al., 2016) and Costa Concordia (Grappi \& Romani, 2015), have been involved in 
significant crises that caused severe problems for them. Consequently, scholars are increasingly interested in analyzing the emergence of crises and the strategies that can be used to face them (Claeys \& Cauberghe, 2014; Coombs, 2016; Corciolani, Gistri, \& Pace, 2016; Pace, Balboni, \& Gistri, 2017). In this article, we consider an actual crisis that recently struck an important brand in the fashion sector-Moncler. Our choice is motivated by two important factors. First, we observed that most research contributions in the crisismanagement field do not consider real crises. Moreover, we focus on a preventable type of crisis, which is the most serious in terms of damage to brand reputation (Coombs, 2007). Especially, experimental studies have tended to analyze and compare alternative types of simulated — and thus fictional—crises (Coombs \& Holladay, 2008; Dawar \& Lei, 2009). While we agree that these approaches hold important methodological strengths, we think that it is relevant to understanding how individuals react in real crisis situations such as that recently faced by Moncler in Italy.

The second reason for choosing our topic is that we believe the fashion sector is an understudied field in the crisis-management domain. Yet, there are some cases of important crises that have recently taken place in this sector. For example, H\&M had to cope with several crises in a short period that involved different stakeholders. In 2011, the company was criticized because of the toxic chemical components ${ }^{1}$ that Greenpeace found after testing some of their clothing (Greenpeace, 2011). In 2013, other criticism was related to the poor working conditions at the H\&M suppliers' factories in Bangladesh. In fact, the Rana Plaza factory collapsed, killing over 1,000 workers (Manik \& Yardley, 2013). Similarly, other famous fashion brands, such as Victoria's Secret, which was highly criticized after launching its "Perfect Body" campaign, faced comparable crises in 2014 (Ciambriello, 2014). More

\footnotetext{
${ }^{1}$ Nonylphenol ethoxylates (NPEs) are harmful to the environment and human health.
} 
recently, companies such as Louis Vuitton and Hermes have been accused by animal rights groups of mistreating the crocodiles whose skin is used to make several of their fashion goods (Dalton, 2015). Thus, we think that beyond studying real crises, the crisis-management literature should also look more carefully at crises that occur in the field of fashion. In this article, we aim to fill this important gap.

In this study, we consider the emotional impact of crises on stakeholders. Indeed, the ways in which stakeholders perceive and react to crises, as well as the ways in which organizations may influence these perceptions, are generally deemed to have key importance in the literature (Bundy et al., 2016). Focusing on the emotions raised by a crisis is worthy because a crisis raises strong emotional reactions that drive stakeholder response. In particular, "[a]nger and sympathy are the core emotions in Attribution Theory," which is central to understanding reactions to crises (Coombs, 2007, pp. 165-166). These emotions then affect the effectiveness of the crisis management by the company. In fact "stakeholders respond with different emotions that may influence the effectiveness of a response strategy" (Bundy et al., 2016, p. 13). Drawing from attribution theory, several authors state that individuals are motivated to search for the causes of unexpected and negative events, and these attributions of responsibility can invoke negative emotions and reactions (e.g., Weiner, 1985). Bundy and Pfarrer (2015) also argued that individuals categorize crises into types as part of a heuristic simplification process in which evaluators intuitively combine past experiences and expectations to reduce the complex nature of a situation into easier-tounderstand cognitive schemas. Yet, most contributions in this domain have not fully explored how stakeholders' biases, heuristics, and emotions influence their perceptions and the effectiveness of response strategies. Consequently, an emerging stream of research is now considering these important elements with greater attention. For example, Jin, Pang, and Cameron (2012) showed that stakeholders respond with different emotions that may 
influence the effectiveness of a response strategy. Jin (2014) concluded that the mechanism and function of emotions in crises need to be further explored.

In this article, we aim to more deeply analyze the role of emotions in responses to crises by concentrating on a specific category of stakeholders - the final customers. In fact, it has been shown that in times of crisis, negative customers reaction may pose one of the greatest threats to a company (Grappi \& Romani, 2015). Crises can harm consumers physically, emotionally, and financially, which may lead them to spread negative word-ofmouth publicity, decide not to purchase from the company, or more generally, develop negative evaluations of that company (Claeys \& Cauberghe, 2014). In our case, through a moderated mediation model (Hayes, 2013), we show that final customer responses to a real fashion brand crisis in terms of attitude toward the company (ATC) and purchase intention (PI) may be predicted. Specifically, we demonstrate that the impact of brand identification (BI) on ATC and PI is significantly mediated by anger for high levels of personal crisis relevance (PCR) and by sympathy for average and low PCR levels.

Below, we introduce our theoretical framework, the methodology of our study, and our findings. We conclude by discussing the theoretical and managerial implications of the results and make some suggestions for future research.

\section{Theoretical framework}

\subsection{The mediating role of emotions on consumer reactions to a crisis}

Consumer-felt emotions are important elements in explaining how consumers react to company crises, in particular in the case of preventable crises where the responsibility of the trigger event is ascribed to the company (Coombs, 2007). However, this kind of crisis has been understudied to date (Grappi \& Romani, 2015). Earlier emotion-related crisis communication research focused on the impact of general positive and negative affective 
states on decision-making processes (Jin, 2014). For instance, Coombs and Holladay (2005) proposed that stronger perceptions of crisis responsibility should strengthen negative affect, while lower perceptions of crisis responsibility should be related to positive affect. Recently, crisis-management researchers have begun to explore the effects of discrete emotions in a crisis context, adopting, in particular, attribution theory, which "states that individuals are motivated to search for the causes of unexpected and negative events, and these attributions of responsibility can invoke negative emotions and reactions" (Bundy et al., 2016, p.12). Using attribution theory, Coombs and Holladay (2005) identified sympathy and anger as particularly salient emotions in crisis management. In the same way, Weiner (1995) considered anger and sympathy the two emotions that are most closely linked to perceptions of responsibility. Recent studies have confirmed the importance of attribution theory in crises. For instance, Bundy and Pfarrer (2015) adopted attribution theory to investigate the role of social approval of companies during crises. Xie and Keh (2016) showed that brand reputation impacts the effects of promotion programs on consumer response to a productharm crisis. Whelan and Dawar (2016) found that the attachment style of consumers (whether fearful or secure) has an effect on the attributions of blame in cases of a product-harm crises.

Emotions play a key role in attribution theory_anger and sympathy in particular (Coombs, 2007). Anger is usually experienced when people blame specific agents (e.g., individuals or institutions) for a transgression or injustice (Iyer \& Oldmeadow, 2006). As Jin (2010) pointed out, the public tends to experience anger when facing a demanding offense from a certain organization against them or their wellbeing. Reports of felt anger have been found to increase as perceptions of crisis responsibilities intensify (Coombs \& Holladay, 2005). Other studies have suggested that events that are more relevant for the individual cause stronger emotions (McDonald et al., 2010). We can thus expect that crises touching 
issues that are relevant for the subject will generate strong emotions, such as anger, rather than relatively mild emotions like sympathy.

Sympathy occurs when awareness of the suffering of others elicits feelings of empathy, especially when the suffering is seen as undeserved. Iyer and Oldmeadow (2006) found that witnessing suffering may not always elicit a direct sympathetic response, as sympathy involves an increased sensitivity to and understanding of the feelings of others, as well as a certain detachment from the situation. Therefore, to experience sympathy for a victim, witnesses need to be able to cognitively separate their circumstances from those of the victim (Wispe, 1986). Given this definition, sympathy is likely to be felt among non-victims when they are exposed to a description of a crisis in which they are not directly involved but where the victim's suffering is witnessed and depicted.

Importantly, the processes of consumer attribution of responsibility can trigger emotions that influence consumer reactions to a crisis. In fact, an increased attribution of crisis responsibility tends to generate stronger negative feelings, such as anger, toward the company, while decreasing feelings of sympathy (Coombs, 2007). In turn, these emotions affect consumers' intentions to act. For instance, angry consumers can show that they are motivated to act against the company responsible for the crisis by decreasing their intention to buy the company's products, increasing negative word-of-mouth, and/or developing a more negative attitude toward the company (Coombs \& Holladay, 2005).

\subsection{The role of brand identification in consumers' emotional reactions to a crisis}

Marketing scholars and practitioners have recognized the importance of BI for companies attempting to build deep, meaningful, long-term relationships with their customers (Bhattacharya \& Sen, 2003). To date, identification research has focused primarily on the drivers and implications of customer identification with brands, as well as employee 
identification with the organization (Gammoh et al., 2014; Hughes \& Ahearne, 2010). From a marketing perspective, consumer identification with a company is an active, selective, volitional act motivated by the satisfaction of one or more self-defined needs. Thus, identification with an organization can also occur in the absence of a formal membership, as in the case of consumers and companies, in terms of both for-profit and nonprofit organizations (Scott \& Lane, 2000). Bhattacharya and Sen (2003) postulated that customers develop their sense of themselves by identifying and associating with the companies they favor. They further argued that customer identification is driven by the attractiveness of the company identity and its similarity to their own identity.

Recent research has attempted to link consumer-company identification with important consumer outcomes and company performance. For example, in the service context, Homburg, Wieseke, and Hoyer (2009) empirically tested a social identity-based path to the service-profit chain in which they conceptualized employee and customer-company identification as an important additional route to the conventional satisfaction-based serviceprofit chain that leads to improved customer outcomes (e.g., loyalty, willingness to pay) and firm financial performance. In the customer context, Ahearne, Bhattacharya, and Gruen (2005) found that consumers who identify with the organization are more likely to engage in behaviors, such as positive word-of-mouth, that support the organization. In the same way, Badrinarayanan and Laverie (2011) examined the role of retail salesperson identification with the manufacturer's brand as an important mediator that influences brand advocacy behaviors and sales efforts.

The stakeholders' level of identification with an organization has also been shown to influence their perceptions of a crisis (Zavyalova et al., 2012). For example, high stakeholder identification with an organization can lead them to "circling the wagons," while low identification can lead stakeholders to point the finger at an afflicted organization. However, 
the benefit of high identification has been shown to decrease as a crisis intensifies (Zavyalova et al., 2016).

BI may act as a buffer against the adverse impact of negative information on brands (Trump, 2014). In fact, a stakeholder's position towards the brand-rather than the simple exposure to a crisis - determines his or her interpretation of the crisis and the emotion stems from that interpretation (e.g., see Rai \& Diermeier, 2015). Consumers tend to overlook and downplay any negative information they may receive about a company (or its products) with which they identify, especially when the identification level is high (Bhattacharya \& Sen, 2003). Bergami and Bagozzi (2000) found that when people identify with an organization, their interactions tend to be characterized by courtesy, altruism, and good sportsmanship. These characteristics are likely to cause consumers to make more charitable attributions regarding the company's intentions and responsibilities when things go wrong; thus, they will be more forgiving of the company's mistakes. In other words, just as consumers are likely to forgive themselves for minor mistakes, they will forgive the companies they identify with, especially because identification leads them to trust the company and its intentions (Kramer, 1991).

BI plays a major role in driving the interpretation of a situation and the consequent emotion felt by the customer. Thus, not only is BI a specific form of the brand-customer relationship, it may also drive the elaboration of behaviors. More specifically, customers with low levels of BI may not have much interest in a brand that has been struck by a crisis. Therefore, they do not engage in a deep assessment of the crisis, instead interpreting the crisis at "face value"; that is, they focus on the most serious fact of the crisis, determine the organization bearing the most obvious responsibility, and react instinctively with anger. Although a customer with low identification does not frame the crisis as bearing personal harm, he or she expresses a righteous anger stemming from the awareness that some harm 
has been done to someone else (Romani et al., 2013). Such anger then negatively affects the ATC and PI (Grappi \& Romani, 2015).

Conversely, customers with high BI may perceive the crisis as a threat to his or her customer identity; thus, the customer may defend him/herself by expressing a positive emotion of support for the company (Trump, 2014). Overall, a highly identified customer will express sympathy toward the company by buffering negative reactions to the crisis.

These effects are particularly relevant for fashion brands. Their exclusivity may indeed exacerbate non-customer negative emotions. However, the same exclusivity may lead highly identified customers to feel part of a select group of consumers, and thus, they may express support and sympathy for the brand against the criticism of "outsiders."

\subsection{The moderating role of personal crisis relevance}

The above rationale is further enhanced if we also consider the role of PCR, that is, the importance consumers perceive concerning the seriousness of the crisis. Specifically, the more relevant a crisis is perceived to be, the more diagnostic and effective it is in changing consumers' brand evaluations (Dawar \& Lei, 2009). In fact, “[g]reather personal relevance and implications are expected to act as motivators to carefully scrutinize information about the crisis episode, as well as comments made regarding the crisis by the organization" (Coombs \& Holladay, 2010, p. 642).

Even if BI has been shown to work as a buffer in case of crises, this buffering effect may no longer work when PCR begins to increase. According to appraisal theory, "incidents that are appraised as personally relevant will lead to more active cognitive processing of crisis episodes" (Coombs \& Holladay, 2010, p. 643), and therefore, BI may move in the background. In conditions of high PCR, the consumer engages in detailed evaluations of the severity of the incident and the responsibility of it. This accurate search would likely expose 
the individual to negative aspects and thus solicit negative emotions such as anger. This effect would not occur in the case of low PCR. Trump (2014) found that strongly connected consumers are not so forgiving of a brand transgression if the brand's actions are personally relevant to them or if the negative actions are of an ethical nature rather than related to product performance. Specifically, she finds that the buffering effect emerges only when negative brand actions are not self-relevant for the individual consumer and the negative actions lie in the product—not the ethical—domain.

The emotions of anger and sympathy during a crisis are also related to attribution theory in another way. Consumers tend to attribute agentic mental states (i.e., intentions and willingness) and experiential states (i.e., feelings and emotions) to companies (Rai \& Diermeier, 2015). In case of a crisis, the emotion—whether anger or sympathy—stems from this framing. If the consumers assign some agentic ability to the company, the crisis will likely cause anger rather than sympathy. In fact, the organization is not perceived as a victim worthy of sympathy but rather as a villain responsible for the crisis due to its agentic capability. In contrast, if consumers anthropomorphize the organization as capable of having experiential states, such as feelings and emotions, a crisis may generate sympathy instead of anger (Rai \& Diermeier, 2015). We may list PCR among the mechanisms through which consumers tend toward agentic or experiential perceptions of the organization-and the related anger or sympathy. If the crisis strikes some personal interest for the consumer, we may expect that the agentic role of the company will be salient, because the consumer knows enough about the company and the sector to recognize its possible role in causing the crisis. This situation would prime anger as the emotional reaction, but in the case of low PCR, we may expect that the crisis would prime sympathy as the organization is not known well enough to attribute agentic abilities; in this situation, some experiential state (such as being victim of the crisis) may arise instead. 
Given the above theoretical observations, we may expect an asymmetry between anger and sympathy depending on the level of PCR. More specifically, we may expect that a high PCR will prime anger, while a low PCR will prime sympathy. The two emotions should mediate the effect of brand identification on consumers' reactions.

We formalize the reflections described above in the following hypotheses:

$H_{1}: P C R$ interacts with BI to influence the felt anger, which in turn, will influence consumers' (a) ATC and (b) PI. The higher the PCR, the greater the consumers' felt anger.

$\mathrm{H}_{2}$ : PCR interacts with BI to influence the felt sympathy, which in turn, will influence consumers' (a) ATC and (b) PI. The lower the PCR, the greater the consumers' felt sympathy.

[Insert Figure 1 near here]

\section{Research method}

Our investigation focuses on the recent brand crisis experienced by the company Moncler in the Italian market. Moncler is a fashion apparel manufacturer known for its sportswear and quilted jackets. On November 2, 2014, a crisis struck the brand. The Italian television newsmagazine Report $^{2}$ released a journalistic inquiry on the illegal practice of the live plucking of geese in certain regions of Eastern Europe. The news program linked this practice to the manufacturing of the Moncler down jackets. The inquiry also showed the outsourcing of some phases of the manufacturing and the extremely high margins of the fashion industry,

\footnotetext{
${ }^{2}$ Report is an Italian television program that has been conducting journalistic investigations since
} September 1997. Since the beginning, the program has had a good audience (2-3 million viewers), and its investigations are considered serious and believable. 
with production costs in the order of $€ 30-50$ and retail prices in the range of $€ 1,500-2,000$ for a jacket or dress. The inquiry fueled a public debate, and there was an uproar against fashion companies, especially the Moncler brand.

Soon after the broadcast, Moncler's reputation on social networks collapsed, with an unusual number of negative comments. Many commentators launched an analysis of the data of Moncler's stock market performance, noting a $5 \% \operatorname{loss}^{3}$ and attributing this to the company's declining corporate reputation on the web. Immediately after the broadcast, Moncler issued a press release where it clarified that their suppliers of feathers complied with the principles of the European Down and Feather Association. It also presented a defense regarding the other business practices cited in the news report.

The crisis endured by Moncler was complex, involving several aspects of its activity. Importantly, the main accusation against Moncler regarded the treatment of geese, and this could be classified as a preventable type of crisis (Coombs, 2007). In addition, the accusation referred to the entire fashion sector in terms of its prices, which were perceived as unjustified, and the practice of outsourcing manufacturing during an economic downturn. According to consumer perception, in fact, companies should support their own national economies during difficult economic times instead of outsourcing production.

To collect data on consumers' reactions to this crisis, we created a questionnaire and ran a web survey through Survey Monkey. The study was conducted at the beginning of November 2014, in the two weeks after the crisis event. Because the focus was on Moncler consumers, we recruited our informants among people who were shopping in three citycenter shopping areas in Italy. Three interviewers distributed about 500 flyers containing a

\footnotetext{
${ }^{3}$ In closing data for October 31, the company's stocks were worth $€ 11.06$ euros; by November 3, they had fallen to $€ 10.52$.
} 
link to our online questionnaire. Of the individuals approached, $27.6 \%$ agreed to take part of the survey by clicking on the link and completing the questionnaire. However, in order to be sure that respondents were real Moncler consumers, at the beginning of the survey we asked whether they had bought at least one Moncler product in the last five years. If the response was no, the respondent could not take the survey. In the end, 115 Moncler consumers $(70.4 \%$ women; mean age 28.35 years; MSc. graduate $53.5 \%$ ) participated to the survey on a voluntary basis, while twenty-three individuals $(9.66 \%)$ were excluded from the survey because they did not meet the criteria for being a current Moncler customer.

The first part of the questionnaire measured the respondent's level of BI with Moncler. It then reminded them of the recent Moncler crisis, detailing the allegations against the company put forward by the television program (Report). The second part of the questionnaire included previously tested scales that were used to measure the dependent, moderating, and mediating variables. In the last section, some sociodemographic items were included. After finishing, respondents were debriefed about the purpose of the study and thanked. To ensure the independence of the observations, the survey was designed to allow for only one attempt to be completed per internet protocol (IP) address.

All the analyzed variables were measured variables; following common practices in these types of analyses, the moderator and mediators were mean centered. Specifically, the variables were summarized as follows:

- a continuous variable (X) indicating consumer's BI,

- a continuous moderator variable (W) referring to PCR4,

\footnotetext{
${ }^{4}$ In order to measure this construct, we adapted the scale used by Malär, Krohmer, Hoyer, \& Nyffenegger (2011). Instead of measuring the consumers' involvement in a product category, as the authors do, we used the scale to measure the consumers' involvement in the crisis. We thus concluded that individuals that were highly involved in the crisis considered it to be personally
} 
- two continuous mediating variables (M1 and M2) characterizing the two emotions of anger and sympathy, and

- two continuous outcome variables (Y1 and Y2) referring to consumer's ATC and PI for the company's products.

[Insert Table 1 near here]

Table 1 summarizes the means, standard deviations, and reliabilities for the six scales. In all the cases, the reliabilities are above the minimum of 0.70 suggested by Nunnally (1978). We used Process, an SPSS tool that computes conditional indirect effects (Hayes, 2013). We report the results of our analysis in the next section.

\section{Results}

To investigate the effect of the interaction effect between BI and PCR on consumer emotional reactions to a crisis, we considered two dependent variables, namely ATC and PI.

[Insert Table 2 near here]

The measures used in the research were based on established scales (see Table 1 and Appendix A) and modified to fit the research context as necessary. The measurement model fit the data well $(\chi 2=246.16, \mathrm{df}=194, \mathrm{RMSEA}=0.04, \mathrm{CFI}=0.98, \mathrm{TLI}=0.98, \mathrm{SRMR}=$ 0.05). Reliability was measured via the composite reliability (Fornell \& Larcker, 1981) with results indicating that the constructs were reliable as each exceeded the recommended rule of thumb of 0.70 (Nunnally, 1978). Convergent validity was evaluated through an examination of the average variances extracted (see Table 2). All of the average variances extracted were greater than 0.50, indicating convergent validity (Fornell \& Larcker, 1981). Discriminant

relevant. Conversely, consumers that were less involved in the crisis considered it to be not personally relevant. 
validity was tested in accordance with Fornell and Larcker's (1981) criteria, whereby the average variance extracted for the construct was compared with the shared variance between the construct and other variables in the model. The square roots of all constructs' AVEs in Table 2 are greater than the correlations among all constructs of this study. Therefore, the discriminant validity of the measurement is acceptable.

[Insert Table 3 near here]

As indicated in Table 3, under the mediator variable model, we found that BI and PCR interact significantly to influence anger $(-0.52, t=-2.20, p<0.05)$ and sympathy $(-0.30, t=-1.99, p<0.05)$. Under the outcome variable model, we found that anger and sympathy both have a significant effect on ATC (anger: $-0.16, t=-2.42, p<0.05$; sympathy: $0.46, t=4.06, p<0.001)$. Given the significant interaction effect between BI and PCR on anger and sympathy, we investigated the indirect effects by estimating the conditional indirect effects at certain values of the moderator. We considered the conditional indirect effects if they were significantly different from zero at $\alpha=0.05$, which means that they do not contain zero in each bootstrap interval. As Table 3 clarifies, for high levels of PCR, anger mediates the impact of BI on ATC, while sympathy does not have a significant effect. Instead, for medium and low levels of PCR, sympathy mediates the impact of BI on ATC, while anger does not have a significant effect.

[Insert Table 4 near here]

As indicated in Table 4, under the mediator variable model, we found that BI and PCR interact significantly to influence anger $(-0.52, t=-2.20, p<0.05)$ and sympathy $(-0.30, t=-1.99, p<0.05)$. Under the outcome variable model, we found that anger and sympathy have different effects on PI (anger: $-0.12, t=-1.33, p>0.05$; sympathy: $0.61, t=$ 3.99, $p<0.001)$. 
Given the significant interaction between BI and PCR on anger and sympathy, we investigated the indirect effects by estimating the conditional indirect effects at certain values of the moderator. As Table 4 illustrates, for high levels of PCR, anger mediates the effect of BI on PI, while sympathy does not have a significant effect. Conversely, for medium and low levels of PCR, sympathy mediates the effect of BI on PI, while anger does not have a significant effect.

In sum, these results confirm that for both our outcome variables (i.e., ATC and PI), the indirect effect of BI via anger works when PCR is high rather than low, thereby supporting $H_{1}$. Conversely, the indirect effect of BI via sympathy works when PCR is low rather than high, supporting $H_{2}$.

\section{Discussion}

We found two different emotional patterns of customer reactions after a fashion brand crisis based on the perception of PCR. When customers perceive the crisis as highly relevant, the emotion that mediates the impact of BI on ATC and PI is anger. In contrast, when the crisis is perceived as having low relevance, the emotion that mediates the impact of BI on ATC and PI is sympathy.

These results confirm the theoretical expectations illustrated above. A crisis triggers different emotional paths depending on PCR. The results are in accordance with some streams of research concerning the role of emotions, which can perform different functions (Pfister \& Bohm, 2008); the function of emotions like anger and sympathy is to support the individual's commitment and relate to moral decisions and judgements. As Pfister and Bohm (2008, p. 14) clarified, the "commitment function enables social coordination by committing people to stick to their decisions, even against their short-term self-interest. Guilt, for example, prevents defection in social dilemmas, and thus guides decision making in strategic 
choice situations." In the case of a crisis, anger and sympathy facilitate the individual's alignment with his or her moral evaluation of the situation and the company. Thus, emotions help drive the connection between BI and the effects of the crisis.

\section{Implications, limitations, and future development}

A significant finding in this study is that different levels of BI tend to activate alternative emotions towards the crisis (i.e., anger or sympathy), and these emotions have a significant impact on ATC and PI. The findings of this study shed light on one key aspect of best practice in crisis communication, which aims at maximizing mutual understanding and closing gaps between the public's coping strategies and the organization's responses. Organizations should identify the intensity of different emotions experienced by the public during various crises and understand the public's emotional needs and coping strategy preferences; this will allow the organizations to strategically choose the most effective response and tailor their crisis-handling messages. Thus, organizations should play the role of coping facilitator in the eyes of the public and utilize sensible and reasonable strategies to accomplish this (Jin, 2014).

In terms of crisis management and communication, a fashion company should distinguish between high and low levels of PCR and act accordingly. People who assign high personal relevance to the crisis are more likely to generate damaging effects for the brand due to the anger they feel and the related weakening of ATC and PI. A "high brand commitment and fashion involvement motivate people to engage in talking about and interacting with fashion brands" (Wolny \& Mueller, 2013, p. 562); fashion-involved consumers' tendency to engage in word-of-mouth, which becomes negative for the brand when it is a way to vent the anger generated by the crisis and share the depressed attitude toward the brand. 
The relevance of a crisis stems from two elements, namely the issue that is affected by the crisis (in the case of our work, animal welfare and the fair treatment of animals; other issues can be ecology, economy, etc.) and the industry (in our case, fashion; other industries can be sports, luxury, entrainment, outdoor activities, etc.). People may be interested in the issue or the industry. Concerning the industry, fashion usually raises interest and relevance for a wide portion of the market. This "personal relevance [of fashion] occurs because the individual relates the product to his self-image and attributes some hedonic qualities to the product" (Wolny \& Mueller, 2013, p. 566). A fashion company is thus at the center of a context that stimulates personal relevance and involvement with the consequences seen above. Fashion is a cultural field where customers can exert strong pressure. For instance, socalled fatshionistas (Scaraboto \& Fischer, 2012) can promote radical institutional changes in the fashion field. Customer pressure may create controversy and escalate into crises. In any case, fashion brands are under heightened scrutiny in the market.

In terms of crisis communication, a fashion company should pay special attention to soothing the anger of customers who attach high relevance to the crisis. Previous studies have suggested that the severity of the moral violation is a key antecedent of customer outrage and that it is even more important than blame assignment. Consequently, "[r]ather than arguing with the media over culpability," companies should "focus on perceptions of the consequences and redressing the problems caused" (Antonetti \& Maklan, 2016, p. 440). Our results further suggest that, in the fashion field, personal relevance plays a role in the emergence of anger and its effects. Future studies may investigate the role of anger and related, but different, emotions such as moral outrage, (Antonetti \& Maklan, 2016) in crises.

While addressing the anger of some consumers is a central element for crisis management, one can also consider sympathy as a potential support for the brand during a crisis. For consumers who do not assign a high relevance to the crisis, sympathy may play a 
positive role that the company can use. In terms of communication, the brand managers can use channels and media outlets that are not addressed to people who are interested in fashion to further raise sympathy. The company can show the positive aspects of the brand that apply in the crisis. For instance, if the brand is in the middle of an environmental crisis, emphasizing good working conditions for employees, fair financial management, and other positive aspects may elicit sympathy in those consumers who do not assign high relevance to the crisis. Situational crisis communication theory (Coombs \& Holladay, 2008; 2010) provides a spectrum of possible crisis commincation strategies, ranging from full apology to attack-the-accuser strategies. Our study suggests that a differentiated crisis communication may be effective, combining apology-based communication to treat the anger of highly involved consumers and ingratiation strategy for less involved consumers.

As for the brand here studied, the immediate reaction by Moncler at the outset of the crisis was to deny any accusations of animal mistreatment and confirm that the brand used only "goose down from suppliers who were bound by contract to protect the welfare of animals" (Za, 2014). The press statement by the brand further indicated that there was "no link whatsoever with the strong images broadcast relating to breeders, suppliers and farms that act in an improper and illegal way" $(\mathrm{Za}, 2014)$. This statement shows that the brand addressed some of the emotional stress caused by the images seen on the television program, providing some preliminary indications that the brand dealt with emotions in its crisis communication. Further studies may deepen the actual strategy used by the brand and its effects, in particular with reference to emotions, which usually fade away with time. In fact, the Moncler crisis emerged in a situation of highly-charged emotions (i.e., the images shown by the television program) and further studies may investigate whether these emotions have lasting effects on the brand. These studies could also better explain the role the company may have had in causing the effects we found in our study. Since we submitted our questionnaire 
in the first two weeks of the crisis, in which Moncler only issued a press release, we think it is unlikely that our informants' responses might have been significantly influenced by it. However, because we did not formally control the possible effect of the company's reaction on consumers, we cannot exclude it either. Therefore, we think that future replications of these results should also examine the role of the company's response to the crisis as a potential explanation of the findings.

Among the limitations of our study, one can also include the lack of specific measurements of the crisis knowledge by the respondents. Given the characteristics of the sample (i.e., Moncler customers) and the widespread notoriety of the crisis, we suspect that the knowledge was high. However, future studies on other types of crises may check for the respondents' knowledge levels about the crisis.

Future research could also shed more light on our results by measuring the consumer's emotional connection to the brand (Escalas, 2004). In this way, it could be possible to further validate the findings of Trump (2014) regarding the connection of consumer reaction and negative brand action. Specifically, it might be interesting to test whether highly connected consumers differ from less connected consumers in reacting to a brand crisis. Finally, in future developments of this study, we have to consider the role of

different kinds of emotions (e.g., disappointment, regret, depression, sadness, etc.) and examine whether these also mediate the relationship between BI and consumer reaction to a crisis event.

\section{Appendix A}

Attitude toward the company (Pope et al., 2004)

1. has good products / does not have good products

2. is well managed / is not well managed 
3. is involved in the community / is not involved in the community

4. responds to consumer needs / does not respond to consumer needs

5. is a good company to work for / is not a good company to work for

Purchase intention (Burton et al., 1999)

1. Would you be more likely or less likely to purchase the product, given the information shown?

more likely / less likely

2. Given the information shown, how probable is it that you would consider the purchase of the product?

very probable / not probable

3. How likely would you be to purchase the product, given the information shown?

very likely / very unlikely

Brand identification (Algesheimer et al., 2005)

1. This brand says a lot about the kind of person I am.

2. This brand's image and my self-image are similar in many respects.

3. This brand plays an important role in my life.

Personal crisis relevance (Malär et al., 2011)

1. Because of my personal attitudes, I feel that this is a crisis that ought to be important to me.

2. Because of my personal values, I feel that this is a crisis that ought to be important to me.

3. This crisis is very important to me personally.

4. Compared with others, this crisis is important to me.

5. I'm interested in this crisis.

Anger (Gelbrich, 2011)

1. I am furious. 


\section{I am outraged.}

3. I feel indignant.

Sympathy (Small \& Verrochi, 2009)

1. I am sympathetic.

2. I feel tender.

3. I am softhearted. 


\section{References}

Ahearne, M., Bhattacharya, C. B., \& Gruen, T. (2005). Antecedents and consequences of customer-company identification: expanding the role of relationship marketing. The Journal of applied psychology, 90(3), 574-585. doi:10.1037/0021-9010.90.3.574

Algesheimer, R., Dholakia, U. M., \& Herrmann, A. (2005). The Social Influence of Brand Community: Evidence from European Car Clubs. Journal of Marketing, 69(3), 19-34. doi:10.1509/jmkg.69.3.19.66363

Antonetti, P., \& Maklan, S. (2016). An Extended Model of Moral Outrage at Corporate Social Irresponsibility. Journal of Business Ethics, 135(3), 429-444. doi:10.1007/s10551-014-2487-y

Badrinarayanan, V., \& Laverie, D. a. (2011). Brand Advocacy and Sales Effort by Retail Salespeople: Antecedents and Influence of Identification with Manufacturers' Brands. Journal of Personal Selling and Sales Management, 31(2), 123-140. doi:10.2753/PSS0885-3134310202

Bergami, M., \& Bagozzi, R. P. (2000). Self Categorization, Affective Commitment and Group Self Esteem as Distinct Aspects of Social Identity in the Organization. British Journal of Social Psychology, 39(4), 555-577.

Bhattacharya, C. B., \& Sen, S. (2003). Consumer-Company Identification: A Framework for Understanding Consumers' Relationships with Companies. Journal of Marketing, 67(2), 76-88. doi:10.1509/jmkg.67.2.76.18609

Bundy, J., \& Pfarrer, M. D. (2015). A burden of responsibility: The role of social approval at the onset of a crisis. Academy of Management Review, 40(3), 345-369. doi:10.5465/amr.2013.0027

Bundy, J., Pfarrer, M. D., Short, C. E., \& Coombs, W. T. (2016). Crises and Crisis Management: Integration, Interpretation, and Research Development. Journal of Management (Vol. 43). doi:10.1177/0149206316680030

Burton, S., Garretson, J. A., \& Velliquette, A. M. (1999). Implications of Accurate Usage of Nutrition Facts Panel Information for Food Product Evaluations and Purchase Intentions. Journal of the Academy of Marketing Science, 27(4), 470-480. doi:10.1177/0092070399274006 
Ciambriello, R. (2014). Real Beauty? Nah, Victoria's Secret Would Rather Celebrate the "Perfect Body." AdWeek. http://www.adweek.com/creativity/real-beauty-nah-victoriassecret-would-rathercelebrate-\%0Aperfect-body-161114/

Claeys, A. S., \& Cauberghe, V. (2014). What makes crisis response strategies work? The impact of crisis involvement and message framing. Journal of Business Research, 67(2), 182-189. doi:10.1016/j.jbusres.2012.10.005

Coombs, W. T. (2007). Protecting organization reputations during a crisis: The development and application of situational crisis communication theory. Corporate Reputation Review, 10(3), 163-176. doi:10.1057/palgrave.crr.1550049

Coombs, W. T. (2016). Reflections on a meta-analysis: Crystallizing thinking about SCCT. Journal of Public Relations Research, 28(2), 120-122. doi:10.1080/1062726X.2016.1167479

Coombs, W. T., \& Holladay, S. J. (2005). An exploratory study of stakeholder emotions; affect and crises. In Research on Emotion in Organizations: Volume 1: The Effect of Affect in Organizational Settings. (pp. 263-280). doi:10.1016/S1746-9791(05)01111-9

Coombs, W. T., \& Holladay, S. J. (2008). Comparing apology to equivalent crisis response strategies: Clarifying apology's role and value in crisis communication. Public Relations Review, 34(3), 252-257. doi:10.1016/j.pubrev.2008.04.001

Coombs, W. T., \& Holladay, S. J. (2010). The Handbook of Crisis Communication. The Handbook of Crisis Communication. doi:10.1002/9781444314885

Corciolani, M., Gistri, G., \& Pace, S. (2016). Exploring the palm oil crisis through the lens of different social media: an analysis of Facebook, Youtube and Twitter contents. Mercati \& Competitività, 4, 43-64.

Dalton, T. (2015). Louis Vuitton and Hermes turn our saltwater crocodiles into high fashion. The Australian. http://www.theaustralian.com.au/life/weekend-australianmagazine/saltwatercrocodiles-\%0Ahigh-fashion-meets-evolutionarydesign/newsstory/\%0A5dd554716513843885959a63afb150f0

Dawar, N., \& Lei, J. (2009). Brand crises: The roles of brand familiarity and crisis relevance in determining the impact on brand evaluations. Journal of Business Research, 62(4), 509-516. doi:10.1016/j.jbusres.2008.02.001 
Escalas, E. J. (2004). Narrative Processing: Building Consumer Connections to Brands. Journal of Consumer Psychology, 14(1-2), 168-180. doi:10.1207/s15327663jcp1401\&2_19

Fornell, C., \& Larcker, D. F. (1981). Evaluating structural equation models with unobservable variables and measurements error. Journal of Marketing Research, 18(4), $39-50$.

Gammoh, B. S., Mallin, M. L., \& Pullins, E. B. (2014). Antecedents and Consequences of Salesperson Identification with the Brand and Company. Journal of Personal Selling \& Sales Management, 34(1), 3-18. doi:10.1080/08853134.2013.870181

Gelbrich, K. (2011). I Have Paid Less Than You! The Emotional and Behavioral Consequences of Advantaged Price Inequality. Journal of Retailing, 87(2), 207-224. doi:10.1016/j.jretai.2011.03.003

Grappi, S., \& Romani, S. (2015). Company Post-Crisis Communication Strategies and the Psychological Mechanism Underlying Consumer Reactions. Journal of Public Relations Research, 27(1), 22-45. doi:10.1080/1062726X.2014.924839

Greenpeace. (2011). Will H\&M make "Detox" the new must-have? Greenpeace. http://www.greenpeace.org/international/en/news/features/hm-detox/. Accessed 13 September 2011

Hayes, A. (2013). Introduction to mediation, moderation, and conditional process analysis. New York, NY: Guilford. doi:978-1-60918-230-4

Homburg, C., Wieseke, J., \& Hoyer, W. D. (2009). Social identity and the service-profit chain. Journal of Marketing, 73(March), 38-54. doi:10.1509/jmkg.73.2.38

Hughes, D. E., \& Ahearne, M. (2010). Energizing the Reseller's Sales Force:The Power of Brand Identification. Journal of Marketing, 74(4), 81-96. doi:10.1509/jmkg.74.4.81

Iyer, A., \& Oldmeadow, J. (2006). Picture this: Emotional and political responses to photographs of the Kenneth Bigley kidnapping. European Journal of Social Psychology, 36(5), 635-647. doi:10.1002/ejsp.316

Jin, Y. (2010). Making sense sensibly in crisis communication: How publics' crisis appraisals influence their negative emotions, coping strategy preferences, and crisis response acceptance. Communication Research, 37(4), 522-552. doi:10.1177/0093650210368256 
Jin, Y. (2014). Examining Publics' Crisis Responses According to Different Shades of Anger and Sympathy. Journal of Public Relations Research, 26(1), 79-101. doi:10.1080/1062726X.2013.848143

Jin, Y., Pang, A., \& Cameron, G. T. (2012). Toward a Publics-Driven, Emotion-Based Conceptualization in Crisis Communication: Unearthing Dominant Emotions in MultiStaged Testing of the Integrated Crisis Mapping (ICM) Model. Journal of Public Relations Research, 24(3), 266-298. doi:10.1080/1062726X.2012.676747

Kramer, R. M. (1991). Intergroup Relations and Organizational Dilemmas: The role of Categorization Processes. Research in Organizational Behavior (Vol. 13).

Malär, L., Krohmer, H., Hoyer, W. D., \& Nyffenegger, B. (2011). Emotional Brand Attachment and Brand Personality: The Relative Importance of the Actual and the Ideal Self. Journal of Marketing, 75(July), 35-52. doi:10.1509/jmkg.75.4.35

Manik, J. A., \& Yardley, J. (2013). Building Collapse in Bangladesh Leaves Scores Dead. New York Times. http://www.nytimes.com/2013/04/25/world/asia/bangladesh-buildingcollapse.html

McDonald, L. M., Sparks, B., \& Glendon, A. I. (2010). Stakeholder reactions to company crisis communication and causes. Public Relations Review, 36(3), 263-271. doi:10.1016/j.pubrev.2010.04.004

Nunnally, J. (1978). Psychometric Theory. New York: McGraw-Hill. doi:10.1037/018882

Pace, S., Balboni, B., \& Gistri, G. (2017). The effects of social media on brand attitude and WOM during a brand crisis: Evidences from the Barilla case. Journal of Marketing Communications, 23(2), 135-148. doi:10.1080/13527266.2014.966478

Pfister, H.-R., \& Bohm, G. (2008). The multiplicity of emotions: A framework of emotional functions in decision making. Judgment and Decision Making, 3(1), 5-17. doi:10.1111/1467-8721.00203\r10.1037/0003-066x.58.9.697.|r10.1037/00332909.127.2.267\r10.1146/annurev.psych.56.091103.070234\r10.1037/033295x.110.1.145

Pope, N. K. L., Voges, K. E., \& Brown, M. R. (2004). The effect of provocation in the form of mild erotica on attitude to the ad and corporate image : Differences between causerelated and product-based advertising. Journal of Advertising, 33(1), 69-82. 
doi:10.1080/00913367.2004.10639154

Rai, T. S., \& Diermeier, D. (2015). Corporations are Cyborgs: Organizations elicit anger but not sympathy when they can think but cannot feel. Organizational Behavior and Human Decision Processes, 126, 18-26. doi:10.1016/j.obhdp.2014.10.001

Romani, S., Grappi, S., \& Bagozzi, R. (2013). My Anger Is Your Gain, My Contempt Your Loss: Explaining Consumer Responses to Corporate Wrongdoing. Psychology \& Marketing, 30(12), 1029-1042. doi:10.1002/mar

Scaraboto, D., \& Fischer, E. (2012). Frustrated Fatshionistas: An Institutional Theory Perspective on Consumer Quests for Greater Choice in Mainstream Markets. Journal of Consumer Research, 39(6), 000-000. doi:10.1086/668298

Scott, S. G., \& Lane, V. R. (2000). A stakeholder approach to organizational identity. Academy of Management Review, 25(1), 43-62. doi:10.5465/amr.2000.2791602

Siano, A., Vollero, A., Conte, F., \& Amabile, S. (2016). "More than words": Expanding the taxonomy of greenwashing after the Volkswagen scandal. Journal of Business Research, 71, 27-37. doi:10.1016/j.jbusres.2016.11.002

Small, D. A., \& Verrochi, N. M. (2009). The Face of Need: Facial Emotion Expression on Charity Advertisements. Journal of Marketing Research, 46(6), 777-787. doi:10.1509/jmkr.46.6.777

Trump, R. K. (2014). Connected consumers' responses to negative brand actions: The roles of transgression self-relevance and domain. Journal of Business Research, 67(9), 18241830. doi:10.1016/j.jbusres.2013.12.007

Weiner, B. (1985). An attributional theory of achievement motivation and emotion. Psychological Review, 92(4), 548-573. doi:10.1037/0033-295X.92.4.548

Weiner, B. (1995). Judgments of responsibility: A foundation for a theory of social conduct. Journal of separation science. doi:10.1002/jssc.201000660

Whelan, J., \& Dawar, N. (2016). Attributions of blame following a product-harm crisis depend on consumers' attachment styles. Marketing Letters, 27(2), 285-294. doi:10.1007/s11002-014-9340-z

Wispe, L. (1986). The Distinction Between Sympathy and Empathy: To Call Forth a Concept, A Word Is Needed. Journal of Personality and Social Psychology, 50(2), 314- 
321. doi:10.1037/0022-3514.50.2.314

Wolny, J., \& Mueller, C. (2013). Analysis of fashion consumers' motives to engage in electronic word of mouth communication through social media platforms. Journal of Marketing Management, 29(5-6), 562-583. doi:10.1080/0267257X.2013.778324

Xie, Y., \& Keh, H. T. (2016). Taming the Blame Game: Using Promotion Programs to Counter Product-Harm Crises. Journal of Advertising, 45(2), 211-226. doi:10.1080/00913367.2015.1134362

Za, V. (2014). Luxury coat maker Moncler denies mistreating geese as shares fall. Reuters. http://www.reuters.com/article/moncler-geese-idUSL6N0ST3PX20141103

Zavyalova, A., Pfarrer, M. D., Reger, R. K., \& Hubbard, T. D. (2016). Reputation as a benefit and a burden? How stakeholders' organizational identification affects the role of reputation following a negative event. Academy of Management Journal, 59(1), 253276. doi:10.5465/amj.2013.0611

Zavyalova, A., Pfarrer, M. D., Reger, R. K., \& Shapiro, D. L. (2012). Managing the message: The effects of firm actions and industry spillovers on media coverage following wrongdoing. Academy of Management Journal, 55(5), 1079-1101. doi:10.5465/amj.2010.0608 
Figure 1. Conceptual model.

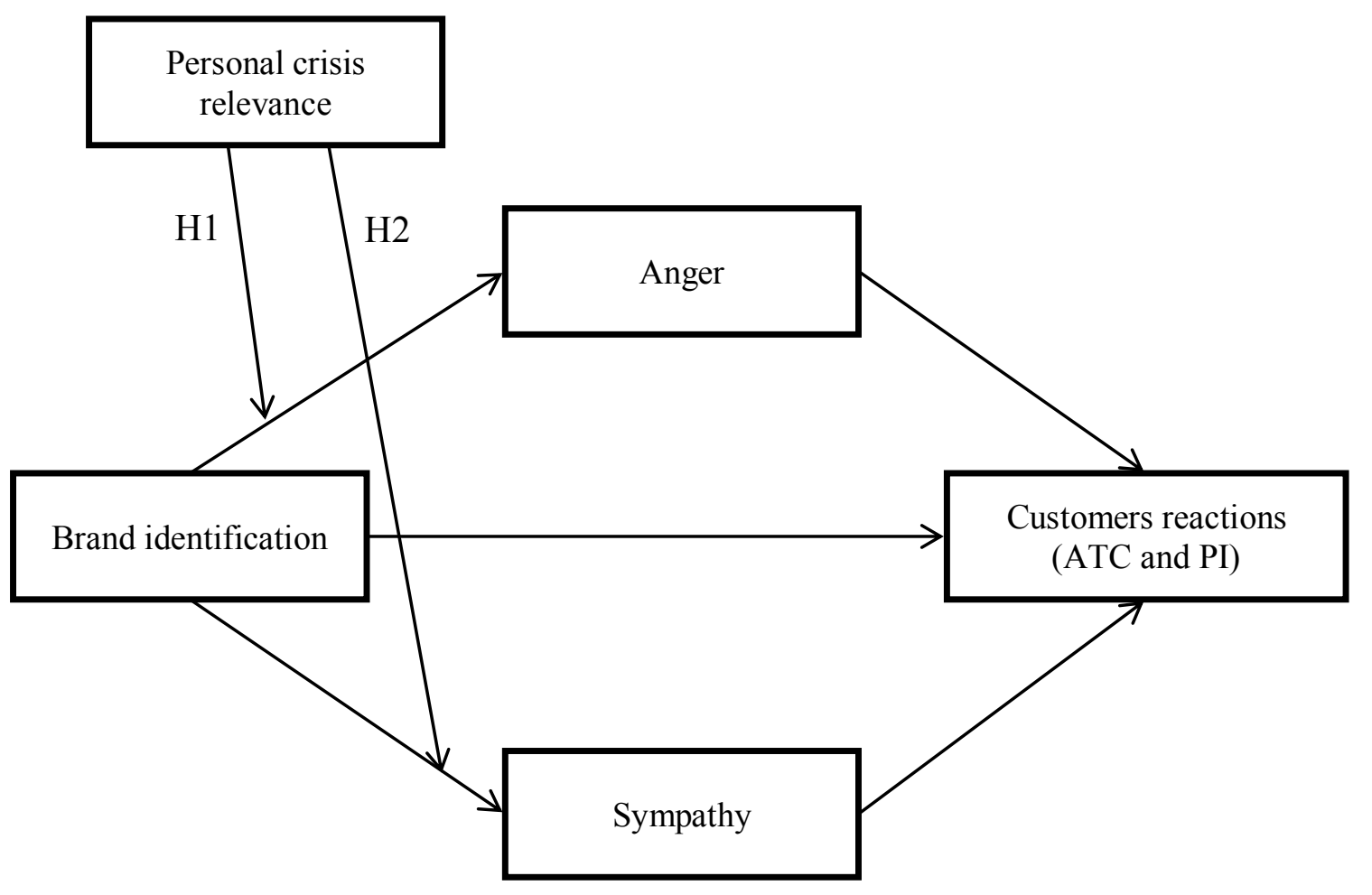


Table 1. Means, standard deviations, and reliabilities of scales

\begin{tabular}{|c|c|c|c|c|}
\hline Scale & Description & Mean & $\begin{array}{l}\text { Standard } \\
\text { deviation }\end{array}$ & $\begin{array}{c}\text { Cronbach's } \\
\text { alpha }(\alpha)\end{array}$ \\
\hline Anger (Gelbrich, 2011) & $\begin{array}{l}3 \text { items, 7-point } \\
\text { Likert }\end{array}$ & 5.25 & 1.45 & 0.83 \\
\hline $\begin{array}{l}\text { Attitude toward the company (Pope, } \\
\text { Voges, \& Brown, 2004) }\end{array}$ & $\begin{array}{c}5 \text { items, 7-point } \\
\text { semantic differential }\end{array}$ & 3.27 & 1.27 & 0.79 \\
\hline $\begin{array}{l}\text { Brand identification (Algesheimer, } \\
\text { Dholakia, \& Herrmann, 2005) }\end{array}$ & $\begin{array}{l}3 \text { items, 10-point } \\
\text { Likert }\end{array}$ & 2.24 & 1.44 & 0.92 \\
\hline $\begin{array}{l}\text { Personal crisis relevance (Malär, } \\
\text { Krohmer, Hoyer, \& Nyffenegger, 2011) }\end{array}$ & $\begin{array}{l}5 \text { items, } 5 \text {-point } \\
\text { Likert }\end{array}$ & 2.60 & 1.16 & 0.92 \\
\hline $\begin{array}{l}\text { Purchase intention (Burton, Garretson, } \\
\& \text { Velliquette, 1999) }\end{array}$ & $\begin{array}{l}3 \text { items, 7-point } \\
\text { Likert }\end{array}$ & 2.49 & 1.65 & 0.93 \\
\hline Sympathy (Small \& Verrochi, 2009) & $\begin{array}{l}3 \text { items, 7-point } \\
\text { Likert }\end{array}$ & 1.78 & 1.02 & 0.83 \\
\hline
\end{tabular}


Table 2. Measurement model results

\begin{tabular}{|c|c|c|c|c|c|c|c|c|}
\hline & Construct & CR & 1 & 2 & 3 & 4 & 5 & 6 \\
\hline (1) & Brand Identification & 0.92 & 0.80 & 0.01 & 0.09 & 0.20 & 0.59 & 0.49 \\
\hline (2) & Personal Crisis Relevance & 0.92 & 0.12 & 0.69 & 0.07 & 0.02 & 0.01 & 0.01 \\
\hline (3) & Anger & 0.83 & -0.31 & 0.28 & 0.63 & 0.41 & 0.22 & 0.15 \\
\hline (4) & Sympathy & 0.84 & 0.45 & -0.15 & -0.64 & 0.64 & 0.32 & 0.23 \\
\hline (5) & Attitude Toward the Company & 0.88 & 0.77 & -0.10 & -0.47 & 0.57 & 0.61 & 0.56 \\
\hline (6) & Purchase Intention & 0.93 & 0.70 & 0.10 & -0.39 & 0.48 & 0.75 & 0.83 \\
\hline
\end{tabular}

Correlations are shown below the diagonal; shared variances are depicted above the diagonal; the AVE is depicted in boldface on the diagonal. 
Table 3. Outcome variable: Attitude toward the company

Mediator variable model: Mediator variable model: $\quad$ Outcome variable model:

\begin{tabular}{cccccc}
\multicolumn{2}{c}{ Anger } & & Sympathy & \multicolumn{2}{c}{ Attitude toward the corporate } \\
\hline$B$ & & $t$ & $B$ & $t$ & $B$
\end{tabular}

\begin{tabular}{lllll}
\hline X: brand & -0.24 & 0.87 & 0.57 & $3.15^{* * *}$
\end{tabular}

identification

W: personal crisis

relevance

$0.57 \quad 4.84 * * * \quad-0.13 \quad-1.70$

$\begin{array}{lllll}\mathbf{X} * \mathbf{W} & -0.52 & -2.20 * & -0.30 & -1.99 *\end{array}$

$M_{1}$ : anger

$\begin{array}{ll}-0.16 & -2.42 * \\ 0.46 & 4.06 * * *\end{array}$

M2: sympathy

$0.46-4.06 * * *$

X: brand

identification

$0.442 .08^{*}$

Conditional indirect effect(s) of $\mathrm{X}$ on $\mathrm{Y}$ at values of the moderator(s)

Bootstrap 95\% Confidence Intervals for Conditional Indirect Effect

\begin{tabular}{lcccc}
\hline & Personal crisis relevance & Effect & Lower & Upper \\
\hline \multirow{2}{*}{ Anger } & -1.16 & -0.06 & -0.29 & 0.06 \\
& 0.00 & 0.04 & -0.03 & 0.20 \\
& $\mathbf{1 . 1 6}$ & $\mathbf{0 . 1 3}$ & $\mathbf{0 . 0 2}$ & $\mathbf{0 . 4 0}$ \\
Sympathy & $-\mathbf{1 . 1 6}$ & $\mathbf{0 . 4 2}$ & $\mathbf{0 . 1 5}$ & $\mathbf{0 . 7 6}$ \\
& $\mathbf{0 . 0 0}$ & $\mathbf{0 . 2 6}$ & $\mathbf{0 . 0 9}$ & $\mathbf{0 . 5 2}$ \\
& 1.16 & 0.11 & -0.07 & 0.37 \\
\hline
\end{tabular}

$R^{2} 0.28 ; * p<.05 ; * * p<.01 ; * * * \mathrm{p}<.001 ; \mathrm{W}:$ moderator, M: mediator, X: predictor 
Table 4. Outcome variable: Purchase intention

Mediator variable model: Mediator variable model: $\quad$ Outcome variable model:

\begin{tabular}{ccccccc}
\multicolumn{2}{c}{ Anger } & & Sympathy & \multicolumn{2}{c}{ Purchase intention } \\
\hline$B$ & $t$ & $B$ & $t$ & $B$ & $t$
\end{tabular}

\begin{tabular}{lllll}
\hline X: brand & -0.24 & -0.87 & 0.57 & $3.15^{* * *}$
\end{tabular}

identification

W: personal crisis

relevance

$0.57 \quad 4.85^{* * *} \quad-0.13 \quad-1.70$

$\mathbf{X} * \mathbf{W}$

$-0.52$

$-2.20 * \quad-0.30$

$-1.99 *$

$M_{1}$ : anger

$-0.12$

$-1.33$

M2: sympathy

0.61

$3.99 * * *$

X: brand

identification

0.48

1.70

Conditional indirect effect(s) of $\mathrm{X}$ on $\mathrm{Y}$ at values of the moderator(s)

Bootstrap 95\% Confidence Intervals for Conditional Indirect Effect

\begin{tabular}{lcccc}
\hline & Personal crisis relevance & Effect & Lower & Upper \\
\hline \multirow{2}{*}{ Anger } & -1.16 & 0.04 & -0.20 & 0.04 \\
& 0.00 & 0.02 & -0.02 & 0.15 \\
& $\mathbf{1 . 1 6}$ & $\mathbf{0 . 0 9}$ & $\mathbf{0 . 0 0}$ & $\mathbf{0 . 2 6}$ \\
& $-\mathbf{1 . 1 6}$ & $\mathbf{0 . 5 5}$ & $\mathbf{0 . 1 7}$ & $\mathbf{1 . 0 6}$ \\
Sympathy & $\mathbf{0 . 0 0}$ & $\mathbf{0 . 3 5}$ & $\mathbf{0 . 1 1}$ & $\mathbf{0 . 7 4}$ \\
& 1.16 & 0.14 & -0.10 & 0.53 \\
\hline
\end{tabular}

$R^{2} 0.21 ;{ }^{*} \mathrm{p}<.05 ;{ }^{* *} \mathrm{p}<.01 ; * * * \mathrm{p}<.001 ; \mathrm{W}:$ moderator, M: mediator, X: predictor 